\title{
PEMAKSAAN ZAKAT OLEH PEMERINTAH DALAM PERSPEKTIF HUKUM ISLAM DAN PENERAPANNYA DI INDONESIA
}

\section{THE IMPOSITION OF ZAKAT BY THE GOVERNMENT IN THE PERSPECTIVE OF ISLAMIC LAW AND ITS APPLICATION IN INDONESIA}

\author{
Khaerul Aqbar \\ Sekolah Tinggi Ilmu Islam dan Bahasa Arab (STIBA) Makassar \\ Email:khaerul@stiba.ac.id \\ Sulkifli Herman \\ Sekolah Tinggi Ilmu Islam dan Bahasa Arab (STIBA) Makassar \\ Email: sulkifliherman@stiba.ac.id \\ Asri \\ Sekolah Tinggi Ilmu Islam dan Bahasa Arab (STIBA) Makassar \\ Email: asri@stiba.ac.id
}

\begin{tabular}{|c|c|}
\hline Keywords : & ABSTRACT \\
\hline $\begin{array}{l}\text { Zakat, Imposition of zakat, } \\
\text { Khulafaurrasyidin. }\end{array}$ & $\begin{array}{l}\text { This study aims to examine how the application of zakat at the time } \\
\text { of the Prophet. and khulafaurasyidin as well as examining how the } \\
\text { zakat enforcement system in Indonesia and its application from the } \\
\text { perspective of Islamic law. In this study, the authors use a type of } \\
\text { library research (library research) whose data sources are } \\
\text { obtained from written sources, including books, laws, figh books, } \\
\text { journals, the internet, and other scientific papers related to the } \\
\text { object under study, by using Sharia normative theological } \\
\text { approach, juridical approach, and sociological approach. The } \\
\text { research results found by researchers are as follows; First, zakat is } \\
\text { one of the pillars in supporting the economy of Muslims to } \\
\text { overcome economic, social, educational, and health disparities in } \\
\text { the country of Indonesia. second; The imposition of zakat in } \\
\text { Indonesia can be done by revising the contents of law number } 23 \text { of } \\
\text { 2011, which is to reduce tax for muzakki on zakat that has been } \\
\text { fulfilled. third; the government can impose zakat on the Indonesian } \\
\text { Muslim community as long as it can manage zakat by the Sharia } \\
\text { without any element of cheating in it. fourth; zakat can be enforced } \\
\text { in Indonesia if it can strengthen the role of BAZNAS, LAZ, and BAZ } \\
\text { nationally by Article } 23 \text { of } 2011 \text { Law. Fifth; the imposition and } \\
\text { management of zakat at the time of the Prophet and } \\
\text { khulafaurrasyidin is something that should be emulated because } \\
\text { history has proven its success in managing zakat. sixth; muzakki } \\
\text { may distribute their zakat directly to mustahik without going } \\
\text { through institutions either from the government or institutions } \\
\text { under the protection of the government. seventh; according to the } \\
\text { perspective of the Islamic law that every leader who manages the } \\
\text { affairs of the Muslims is obliged to take care of his affairs by the } \\
\text { provisions of the Shari'a. Eighth; in surah al-Taubah / } 9 \text { verse } 103 \\
\text { the leaders have been instructed to take zakat from Muslims by } \\
\text { applicable regulations. }\end{array}$ \\
\hline
\end{tabular}




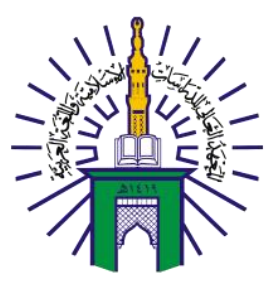

\section{BUSTANUL FUQAHA: \\ JURNAL BIDANG HUKUM ISLAM \\ Vol. 2 No. 1 (2021): Hal. 78-97 \\ EISSN: 2723-6021 \\ Website: https://journal.stiba.ac.id}

\begin{tabular}{|c|c|c|}
\hline \multirow{2}{*}{$\begin{array}{l}\text { Kata kunci : } \\
\text { Zakat, Pemaksaan } \\
\text { Khulafaurrasyidin. }\end{array}$} & \multirow[b]{2}{*}{ Zakat, } & ABSTRAK \\
\hline & & $\begin{array}{l}\text { Penelitian ini bertujuan untuk mengkaji bagaimana penerapan zakat } \\
\text { pada masa Rasulullah saw. dan khulafaurasyidin serta mengkaji } \\
\text { bagaimana sistem pemaksaan zakat di Indonesia dan penerapannya } \\
\text { dalam perspektif hukum Islam. Dalam penelitian ini, penulis } \\
\text { menggunakan jenis penelitian pustaka (library research) yang } \\
\text { sumber datanya diperoleh dari sumber tertulis, mencakup buku- } \\
\text { buku, undang-undang, kitab fikih, jurnal, internet dan karya tulis } \\
\text { ilmiyah lain yang berhubungan dengan objek yang diteliti, dengan } \\
\text { menggunakan metode pendekatan teologi normatif syariah, } \\
\text { pendekatan yuridis dan pendekatan sosiologis. Hasil penelitian } \\
\text { yang ditemukan peneliti adalah sebagai berikut; Pertama, zakat } \\
\text { menjadi salah satu pilar dalam mendukung perekonomian umat } \\
\text { Islam untuk mengatasi kesenjangan ekonomi, sosial, pendidikan } \\
\text { dan kesehatan di negara Indonesia. kedua; pemaksaan zakat di } \\
\text { Indonesia dapat dilakukan dengan merevisi isi undang-undang } \\
\text { nomor } 23 \text { tahun } 2011 \text { yaitu mengadakan pengurangan pajak bagi } \\
\text { muzakki terhadap zakat yang telah dipenuhinya. ketiga; pemerintah } \\
\text { dapat memaksakan zakat kepada masyarakat muslim Indonesia } \\
\text { dengan catatan mampu mengelola zakat sesuai dengan syariat tanpa } \\
\text { ada unsur kecurangan di dalamnya. keempat; pemaksaan zakat } \\
\text { dapat dilakukan di negara Indonesia apabila mampu mengukuhkan } \\
\text { peran BAZNAS, LAZ dan BAZ secara nasional sesuai dengan UU } \\
\text { pasal } 23 \text { tahun } 2011 \text {. Kelima; pemaksaan dan pengelolaan zakat } \\
\text { pada zaman Rasulullah dan khulafaurrasyidin merupakan hal yang } \\
\text { patut ditiru karena sejarah telah membuktikan akan keberhasilannya } \\
\text { dalam mengelola zakat. keenam; bolehnya muzakki menyalurkan } \\
\text { zakatnya secara langsung ke mustahik tanpa melalui lembaga baik } \\
\text { dari pemerintah ataupun lembaga dibawah lindungan pemerintah. } \\
\text { ketujuh; menurut perspektif hukum Islam bahwa setiap pemimpin } \\
\text { yang mengurus urusan kaum muslimin wajib mengurus urusannya } \\
\text { sesuai dengan ketentuan syariat. Kedelapan; dalam surah al- } \\
\text { Taubah/9 ayat } 103 \text { telah diperintahkan para pemimpin untuk } \\
\text { mengambil zakat dari umat Islam sesuai dengan ketentuan yang } \\
\text { berlaku. }\end{array}$ \\
\hline
\end{tabular}

Diterima: 2 April 2021; Direvisi: 19 April 2021; Disetujui: 21 April 2021; Tersedia online: 23 April 2021.

How to cite: Aqbar, Haerul., Sulkifli Herman and Asri, "Pemaksaan Zakat oleh Pemerintah dalam Perspektif Hukum Islam dan Penerapannya di Indonesia", BUSTANUL FUQAHA: Jurnal Bidang Hukum Islam 2, No.1 (April 23, 2021): 78-97. doi: https://doi.org/10.36701/bustanul.v2i1.325

\section{PENDAHULUAN}

Zakat merupakan salah satu pilar utama dari ajaran Islam setelah salat serta merupakan penyangga bagi tegaknya Islam dan penunjang perekonomian. ${ }^{1}$ Zakat juga menjadi kewajiban bagi umat Islam yang harus dipenuhi. Allah swt. telah menegaskan bahwa zakat merupakan salah satu rukun dan fardu ain yang wajib ditunaikan oleh

${ }^{1}$ Muhammad Taufan Djafri, dkk. "Zakat Harta dari Hasil Undian Berhadiah dalam Perspektif Hukum Islam.” BUSTANUL FUQAHA: Jurnal Bidang Hukum Islam 1, No. 3 (2020), 392. 
umat Islam yang hartanya telah memenuhi kriteria ${ }^{2}$. Dengan zakat, hubungan antara si kaya dan si miskin menjadi hormanis. Rasa solidaritas orang kaya kepada orang miskin tumbuh seiring dipraktikkannya amalan ini, dan dengan zakat, harta orang kaya dapat disucikan dari kotorannya sehingga menjadi lebih berkah ${ }^{3}$. Syaikh Sulaiman bin Ahmad bin Yahya al-Faifi, berpendapat bahwa hukum orang yang enggan membayar zakat ada perinciannya. Jikalau ia enggan karena mengingkarinya, padahal dia telah memenuhi syarat wajib zakat, maka dia telah kafir menurut ijmak meskipun dia menunaikannya, selama masih mengingkari kewajiban amalan tersebut. Jika dia tidak menunaikan zakat karena bakhil atau malas maka dia orang fasik yang melakukan salah satu dosa besar ${ }^{4}$.

Pada dasarnya dasar merupakan bentuk pengabdian dan ketundukan kepada Aturan Allah swt., sehingga zakat mejadi tembok pemisah antara Islam dengan kufur. ${ }^{5}$ Olehnya itu Abu Bakar Ash-Shiddiq ra. memaklumatkan perang kepada para pengingkar kewajiban zakat, dan memvonis mereka sebagai kafir serta menghalalkan darah mereka ${ }^{6}$. Selanjutnya, pada awal pembentukan konsep baitulmal oleh Umar bin Khattab, pengelolaan dana zakat menjadi otorisasi (pembuatan kebijakan) pusat dengan model sentralisasi ${ }^{7}$, sehingga pemerintah pusat menjadi agent of change $^{8}$ terhadap perubahan kondisi masyarakat, terutama mengangkat harkat dan martabat kaum duafa. Dengan demikian, kewibawaan pemerintah dan ketaatan rakyat tercipta keharmonisan seiring dengan imbangnya pengelolaan zakat kepada masyarakat.

Khususnya negara Indonesia, pemerintah lebih fokus pada pemungutan pajak sedangkan kita ketahui bahwa Indonesia adalah negara yang memiliki penduduk muslim terbanyak di dunia. Jika kita kembali ke zaman mulanya Islam datang ke Indonesia, zakat telah menjadi sumber dana untuk kepentingan dan kemasalahatan kaum muslimin. Sebagaimana di zaman Umar bin Khattab yang memerintahkan para gubernur di zamannya untuk mengambil zakat harta dari si kaya lalu menyalurkannya ke fakir miskin di wilayah kekuasaannya, dan jika kebutuhan zakat telah terpenuhi, maka dapat disalurkan ke daerah lain yang membutuhkan ${ }^{9}$. Adapun di zaman

\footnotetext{
${ }^{2}$ Saprida, Fiqih Zakat, Shodaqoh dan Wakaf (Cet. I; Palembang: Noerfikri, 2015), 3.

${ }^{3}$ Sa'̄̄d bin Alī bin Wahab al-Qaḥțān̄̄, al-Zakāh fĩ al-Islām fì Daui Kitab wa al-Sunnah, (alSu'diyah: Maktab al-Da'wah bil-Qașbi, 2010), 1.

${ }^{4}$ Sulaimān bin Aḥmad bin Yaḥyā al-Faifi, al-Wajīz fì-Fiqh al-Sunnah (Cet. IV; Libanon: Beirut Publishing, 2018), 230.

5 Sulkifli Herman, Saifullah bin Anshor, and Akhmad Hanafi Dain Yunta. "Tinjauan Hukum Islam terhadap Pembayaran Zakat Profesi dengan Sistem Payroll (Studi Kasus pada PT. PLN Persero, Unit Induk Wilayah Sulselbar)." BUSTANUL FUQAHA: Jurnal Bidang Hukum Islam 1.4 (2020): 651

${ }^{6}$ Ahmad Sarwi, Seri Fikih Kehidupan (4): Zakat (Cet. I; Jakarta Selatan: DU Publishing, 2011), 18.

${ }^{7}$ Sentralisasi adalah pengaturan kewenangan dari pemerintah daerah kepada pemerintah pusat untuk mengurus urusah rumah tangganya sendiri berdasarkan prakarsa dan aspirasi dari rakyat. http://id.m.wikipedia.org (15 Mei 2020).

${ }^{8}$ Agent of change ialah orang-orang yang bertindak sebagai pemicu terjadinya sebuah perubahan. https://brainly.co.id (15 Mei 2020).

${ }^{9}$ Aqbar, K., \& Iskandar, A., "Kontekstualisasi Ekonomi Zakat dalam Mengentaskan Kemiskinan: Studi Kebijakan Zakat Umar bin Khattab dan Perzakatan di Indonesia", Laa Maisyir: Jurnal Ekonomi Islam 6 no. 2 (2019), 230.
} 


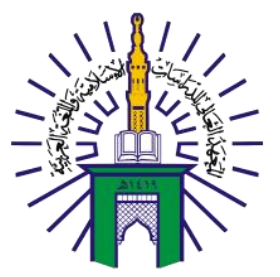

\section{BUSTANUL FUQAHA: \\ JURNAL BIDANG HUKUM ISLAM \\ Vol. 2 No. 1 (2021): Hal. 78-97 \\ EISSN: 2723-6021 \\ Website: https://journal.stiba.ac.id}

penjajahan Belanda, zakatlah yang menjadi dana perjuangan untuk melawan penjajah yang menguasai satu persatu tanah air kita.

Setelah Indonesia memperoleh kemerdekaannya, zakat kembali menjadi perhatian para ekonomi dan ahli fikih bersamaan pemerintah dalam menyusun ekonomi Indonesia. Perhatian pemerintah terhadap lembaga zakat mulai bangkit pada tahun 1962, di mana pemerintah juga mengeluarkan peraturan Menteri Agama nomor 4 dan nomor 5/1968, masing-masing tentang pembentukan Badan Amil Zakat dan pembentukan Baitulmal (Balai Harta Kekayaan) di tingkat pusat, propinsi dan kabupaten. Setahun sebelumya, yakni tahun 1967, pemerintah telah menyiapkan RUU zakat yang akan diajukan kepada DPR untuk disahkan menjadi undang-undang. Namun, Menteri Keuangan pada waktu itu menyatakan bahwa peraturan mengenai zakat tidak perlu dituangkan dalam undang-undang, cukup dengan peraturan menteri agama saja. Oleh karena pendapat tersebut, Menteri Agama menunda pelaksanaan peraturan Menteri Agama No. 4 dan No. 5 tahun 1968 tersebut di atas ${ }^{10}$.

Kemudian beberapa hari setelah itu, pada peringatan Isra' Mi'raj di Istana Negara pada tanggal 22 Oktober 1968, Presiden Soeharto menganjurkan untuk menghimpun zakat secara sistematis dan terorganisasi seperti Badan Amil Zakat Nasional yang dipelopori oleh pemerintah Daerah Khusus Ibukota Jakarta. Dengan dipelopori pemerintah daerah DKI yang pada waktu itu dipimpin oleh Gubernur Ali Sadikin, berdirilah di Ibukota ini Badan Amil Zakat, Infaq dan Sedekah disingkat (BAZIS), dan pada tahun 1968 terbentuk di berbagai daerah ${ }^{11}$.

Berdasarkan paparan di atas, maka disimpulkan beberapa hal: Pertama, Lembaga Amil yang membatasi dirinya dengan hanya mengumpulkan zakat fitrah saja; Kedua, menitikberatkan kegiatannya pada pengumpulan zakat mal atau zakat harta ditambah dengan infak dan sedekah; Ketiga adalah lembaga yang kegiatannya meliputi semua harta yang wajib dizakati.

Zakat emas, perak, uang atau tabungan misalnya, bukan hanya dibayarkan pada bulan Ramadan, tetapi dikeluarkan zakatnya pada saat harta itu telah dimiliki selama setahun terhitung sejak mencapai nisab. Begitu pula dengan zakat perniagaan dan zakat hasil panen yang langsung dikeluarkan zakatnya pada saat panen terjadi. Sebagaimana Allah Ta'ala berfirman dalam Q.S. al- An'am/6: 141.

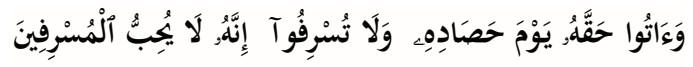

Terjemahnya:

Dan tunaikanlah haknya di hari memetik hasilnya (dengan disedekahkan kepada fakir miskin); dan janganlah kamu berlebih-lebihan. Sesungguhnya Allah tidak menyukai berlebih-lebihan ${ }^{12}$.

Di negara Indonesia, zakat telah didefinisikan secara resmi melalui ketentuan undang-undang sebagai harta yang wajib disisihkan oleh seorang muslim atau badan

\footnotetext{
${ }^{10}$ Faisal, Sejarah Pengelolaan Zakat di Dunia Muslim dan Indonesia, (Lampung: IAIN Raden Intan Lampung, 2011), 259.

${ }^{11}$ Saprida, Fiqih Zakat, Shodaqoh dan Wakaf, 20.

${ }^{12}$ Departemen Agama RI, Alquran dan Terjemahannya, 146.
} 


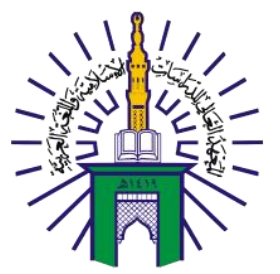

\section{BUSTANUL FUQAHA: \\ JURNAL BIDANG HUKUM ISLAM \\ Vol. 2 No. 1 (2021): Hal. 78-97 \\ EISSN: 2723-6021 \\ Website: https://journal.stiba.ac.id}

amil zakat yang dimiliki orang muslim sesuai dengan ketentuan Islam untuk diberikan kepada yang berhak menerimanya. Untuk itu, pengkajian dapat ditujukan pada fokus tentang: 1) Bagaimana penerapan zakat pada masa Rasulullah saw. dan khulafaurasyidin; dan 2) Bagaimana sistem pemaksaan zakat di Indonesia dan penerapannya dalam perspektif hukum Islam.

Berdasarkan studi pendahuluan ditemukan beberapa hasil kajian yang relevan dengan fokus pengkajian penulis, di antaranya:

1. Penelitian yang dilakukan oleh Siti Habibah pada tahun 2015 dengan judul "Zakat Profesi Dalam Pemikiran Fiqh Kontemporer", di mana hasil penelitiannya menemukan adanya perbedaan pendapat dari tokoh-tokoh ulama dalam menetapkan zakat profesi baik dari metode istinbat maupun ijtihad. Metode istinbat yang digunakan setiap tokoh berbeda seperti Yusuf Qrdhawi dan Didin Hafidhuddin ${ }^{13}$. Adapun pembeda dengan kajian penulis terletak pada fokus pengkajiannya, meski sama-sama mengkaji tentang zakat.

2. Penelitian yang dilakukan oleh Sultan Syahrir dengan judul "Pemahaman masyarakat Terhadap kewajiban zakat di Kecamatan Maritengae Kabupaten Sidenreng Rappang", di mana hasil penelitiannya menyebutkan bahwa pemahaman masyarakat terhadap kewajiban zakat pada umumnya belum memahami makna zakat secara utuh. ${ }^{14}$ Adapun pikiran pembeda dari kajian penulis terletak pada fokus pengkajian terhadap pemerintah dalam memberlakukan pemaksaan zakat terhadap masyarakat berkenaan kebijakan yang dapat dilakukan sehingga zakat bisa diterapkan di masyarakat.

3. Penelitian yang dilakukan oleh Rafiqah Aliyati dengan judul "Penerapan Zakat sebagai Pengurangan Penghasilan Kena Pajak di Kantor Kementerian Agama Kabupaten Gowa”, di mana hasil penelitiannya menyebutkan bahwa zakat sebagai pengurang penghasilan kena pajak memberikan keringanan kepada umat Islam dalam membayar zakat dan pajak, di mana zakat dapat menjadi pengurang kena pajak di Kantor Kementrian Agama Kabupaten Gowa ${ }^{15}$. Adapun pikiran pembeda dengan kajian penulis ialah terletak pada fokus kajian.

Dari ketiga hasil penelitian terdahulu di atas, tampak bahwa belum ditemukan pengkajian secara mendalam berkenaan dengan upaya pemaksaan zakat yang dilakukan oleh pemerintah melalui kebijakannya untuk kesejahteraan rakyat dan relevansinya dalam tinjauan hukum Islam. Oleh karena itu, dalam menemukan jawaban atas fokus kajian tersebut, maka diperlukan cara atau metode yang logis, rasional, dan sistematis. Adapun metode penelitian yang digunakan dalam penelitian ini adalah penelitian kepustakaan (library research), yaitu suatu penelitian yang

\footnotetext{
${ }^{13}$ Siti Habibah, "Zakat Profesi Dalam Pemikiran Fikih Kontemporer (Studi Perspektif Ushul Fikih)", Skripsi (Yogyakarta: Fak. Syariah dan Hukum UIN Sunan Kalijaga, 2015).

${ }^{14}$ Syahrir, Sultan. "Pemahaman Masyarakat Terhadap Kewajiban Zakat di Kecamatan Maritengae Kabupaten Sidenreng Rappang”. Skripsi, (Makassar: Fak. Syariah dan Hukum UIN Alauddin, 2017).

${ }^{15}$ Aliyati, Rafiqah. "Penerapan Zakat Sebagai Pengurang Penghasilan Kena Pajak di Kantor Kementrian Agama Kabupaten". Skripsi (Makassar: Fak. Ekonomi dan Bisnis Islam UIN Alauddin, 2015).
} 
sumber datanya diperoleh dari sumber tertulis, mencakup buku-buku, undang-undang, kitab fikih, jurnal, internet dan karya tulis ilmiah lain yang berhubungan dengan objek yang diteliti ${ }^{16}$. Adapun pendekatan yang digunakan adalah: Pertama, pendekatan teologi normatif (syariah), adalah pendekatan yang memandangan agama dari segi ajarannya yang pokok dan asli dari Tuhan yang di dalamnya tidak terdapat penalaran pemikiran manusia; Kedua, pendekatan yuridis, pendekatan ini digunakan untuk menelusuri sumber hukum dari metode-metode dengan melacak atau mencari pembenarannya melalui undang-undang; dan ketiga, pendekatan sosiologis, pendekatan ini digunakan untuk menggambarkan hubungan mahluk Allah swt. yang ada di muka bumi ini ${ }^{17}$. Di samping itu, teknik analisis data yang digunakan adalah teknik analisis konten (content analysis).

\section{PEMBAHASAN}

\section{Sistem Pemaksaan Zakat di Indonesia}

Sistem pemaksaan zakat di Indonesia merupakan langkah-langkah kebijakan yang harus diambil oleh pemerintah dalam pengelolaan zakat secara kolektif. Di antaranya memiliki manajemen zakat yang terstruktur dengan harapan melahirkan amil zakat yang profesional, amanah, disiplin dan penuh tanggung jawab serta melahirkan kepercayaan dan sambutan hangat dari masyarakat dalam mengumpulkan zakatnya melalui lembaga zakat yang telah dibentuk oleh pemerintah. Selama ini sistem yang ditempuh oleh pemerintah dalam pemberdayaan zakat perlu dikaji lebih mendalam lantaran pengelolaan zakat selama ini belum maksimal. Padahal telah ada upaya yang dilakukan oleh pemerintah mengenai pengelolaan zakat seperti pembentukan UndangUndang Zakat No. 23 Tahun 2011 tentang pengelolaan zakat dan pembentukan Lembaga Amil Zakat (LAZ) di berbagai daerah di Indonesia namun semua ini belum maksimal.

Besarnya penduduk muslim Indonesia tampak berbanding lurus dengan besarnya potensi zakat di negara ini. Potensi zakat di Indonesia yang mencapai 217 triliun rupiah merupakan jumlah yang sangat besar yang dapat menjadi solusi finansial dalam mengatasi permasalahan kemiskinan dan ketimpangan di Indonesia ${ }^{18}$. Sejarah telah membuktikan bahwa zakat mampu mengurangi jumlah keluarga miskin, kesenjangan pendapatan dan tingkat keparahan kemiskinan pada keluarga miskin. Sebagaimana di zaman khalifah Umar bin Abdul Aziz yang menyejahterakan umat Islam melalui upaya pengelolaan zakat ${ }^{19}$. Hal ini menunjukkan bahwa zakat memiliki potensi besar dalam memberantas kemiskinan dan pengangguran serta menyejahterakan manusia. 2010), 9.

${ }^{16}$ Etta Mamang Sangaji dan Sopiah, Metodologi Penelitian (Yogyakarta: C.V. Andi Offset,

${ }^{17}$ Muljono Domopoli, Pedoman Penulisan Karya Tulis Ilmiah Makalah, Skripsi, Tesis, Disertasi, dan Laporan Penelitian, h. 16.

${ }^{18}$ Nikmatuniayah dan Marliyati, Akuntabilitas Laporan Keuangan Lembaga Amil Zakat di Kota Semarang 31, no. 2 (2015), 486.

${ }^{19}$ Aqbar, K., \& Iskandar, A., "Kontekstualisasi Kebijakan Zakat Umar bin Abdul Aziz dalam Perzakatan dan Pengentasan Kemiskinan di Indonesia”, Kajian Ekonomi dan Keuangan 3, no. 3 (2019), 199. 


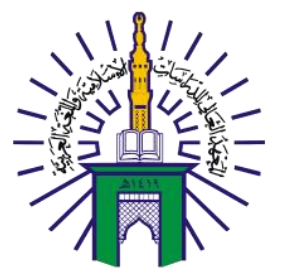

\section{BUSTANUL FUQAHA: \\ JURNAL BIDANG HUKUM ISLAM \\ Vol. 2 No. 1 (2021): Hal. 78-97 \\ EISSN: 2723-6021 \\ Website: https://journal.stiba.ac.id}

Di Provinsi Banten tepatnya di Kota Serang begitu banyak kita temui masyarakat miskin, bahkan ada yang meninggal dikarenakan kelaparan ${ }^{20}$. Jika saja zakat dikelola dengan baik sesuai aturan dan tuntunan ajaran Islam, maka nilai-nilai ritualnya akan mampu mengedukasi masyarakat dalam rangka mengentaskan kemiskinan ${ }^{21}$. Namun, kita ketahui bahwa pengelolaan zakat di Indonesia tidak sebanding dengan yang diharapkan. Berbagai faktor yang menyebabkan ketidakefektifan tata pengelolaan zakat di negeri kita yaitu, disebabkan karena:

1. Kurangnya pengawasan dan dukungan negara untuk proaktif dalam berjalannya UU tentang zakat begitu pula lembaga-lembaga amil zakat. Tugas pemerintah tidak hanya membentuk UU, menyediakan pelayanan dan menciptakan kondisi yang kondusif, tetapi harus ada ketegasan yang ditunjukkan kepada lembaga amil zakat dan para muzakki agar terwujudnya pembangunan ekonomi bersama melalui zakat.

2. Tidak adanya standar baku tentang zakat di tengah heterogenitas masyarakat yang awam terhadap zakat. Masyarakat awam hanya mengetahui pembayaran zakat hanya di bulan Ramadan saja. Mereka hanya mengenal zakat fitrah sedangkan zakat harta mereka tidak mengetahuinya. Hal ini disebabkan hanya orang-orang yang telah mempelajari tentang zakat mengetahui bahwa ada yang dinamakan zakat harta. Dengan demikian, tidak mengherankan ketika banyak menui kontroversi ketika zakat Pegawai Negeri Sipil (PNS) ditetapkan.

3. Lembaga Amil Zakat (LAZ) yang kurang profesional, proaktif dan kurang kedekatannya terhadap masyarakat menyebabkan banyak masyarakat yang menyalurkan zakatnya langsung ke mustahik atau lembaga non-pemerintah karena mereka lebih dekat dengan masyarakat dan lebih terpercaya.

4. Banyaknya pemerintah yang kurang jujur seperti melakukan korupsi dan kepemimpinannya yang buruk dalam menjalankan amanahnya menyebabkan menurunnya tingkat kepercayaan masyarakat terhadap pemerintah.

5. Ketidakpercayaan masyarakat terhadap lembaga yang dibentuk oleh pemerintah yang lemah dan tidak transparan. BAZ yang dibentuk oleh pemerintah masih jauh dari prinsip professional, dan BAZ yang dibentuk di daerah-daerah hanya menerima pengumpulan yang sifatnya masih terbatas pada pegawai negeri seperti zakat profesi dan zakat fitrah di bulan Ramadan. Meskipun tidak semua, tetapi kebanyakan masyarakat lebih memilih mengumpulkan zakatnya di lembagalembaga non-pemerintah karena lebih dipercaya dan lebih fleksibel untuk pengumpulannya.

6. Kesadaran Masyarakat yang kurang terhadap peran zakat bagi perekonomian. Zakat tidak hanya sebatas pemenuhan rukun Islam, namun lebih luas dalam sudut pandang agama, sosial, ekonomi dan kesejahtaraan masyarakat. Menurut data salah satu LAZ terpercaya yaitu Dompet Duafa, menilai potensi zakat di Indonesia bisa mencapai 273 triliun. Namun, realisasinya yang terhimpun baru sekitar 2,73

\footnotetext{
${ }^{20}$ Kabar Banten, "Wali Kota Serang Minta Kejadian Warga Meninggal Kelaparan Tak Terulang”, Situs Resmi Kabar Banten. www.kabar-Banten.com (26 April 2020).

${ }^{21}$ Sultan Syahrir, "Pemahaman Masyarakat Terhadap Kewajiban Zakat di Kecamatan Maritengae Kabupaten Sidenreng Rappang”, Skripsi, h. 3.
} 
triliun, artinya bahwa baru sekitar satu persen zakat yang terhimpun dari potensi zakat yang ada di Indonesia ${ }^{22}$.

Beberapa hal yang berkaitan dengan pengelolaan zakat di Indonesia perlu disebutkan untuk mencapai sistem yang mengharuskan pemerintah melakukan pemaksaan dalam pengumpulan zakat. Yaitu:

\section{Arti Pemaksaan}

Pemaksaan berasal dari kata paksa yaitu artinya mengerjakan sesuatu yang diharuskan walaupun tidak mau ${ }^{23}$. Paksaan atau koersi adalah praktik memaksa pihak lain untuk berperilaku secara spontan (baik melalui tindakan atau tidak bertindak) dengan menggunakan ancaman, imbalan, atau intimidasi. Bisa berbentuk tekanan atau kekuatan $^{24}$. Salah satu contoh ialah kontroversi tentang kebijakan Kementrian Agama dalam sidang mempersiapkan Peraturan Presiden tentang pungutan zakat sebesar 2,5 persen dari gaji bulanan Aparatur Sipil Negara (ASN) atau Pegawai Negeri Sipil (PNS). Hal ini mendapatkan respons beragam, ada yang beranggapan bahwa itu merupakan suatu paksaan karena tidak semua PNS memiliki hidup yang berkecukupan bahkan termasuk yang berhak menerima zakat. Namun, ada pula yang beranggapan bahwa itu bukanlah suatu paksaan karena PNS merupakan suatu profesi dan gaji profesi berhak dikeluarkan zakatnya selama yang bersangkutan telah terpenuhi kebutuhan pokoknya.

Oleh karena itu, dapat disimpulkan bahwa setiap PNS yang memiliki penghidupan yang layak. Di mana, semua bahan pokok dari sisi ekonomi, pendidikan dan kesehatan telah terpenuhi, maka wajib baginya mengeluarkan zakat dari hasil usahanya tersebut. Namun sebaliknya, apabila pegawai PNS tersebut gajinya belum mencukupi kebutuhannya dan kebutuhan orang-orang dibawanya maka tidak wajib baginya memotong gaji bulanannya.

\section{Ditinjau dari Dasar Hukum Zakat}

Di antara redaksi perintah Allah tentang zakat ada pada surat al-Baqarah/2: 43. Yang telah disebutkan ayatnya, Yaitu perintah untuk menunaikan zakat. Sedangkan hukum asal dari perintah adalah wajib. Maka zakat adalah sebuah kewajiban. Setiap perkara yang wajib akan berimplikasi pada pemberian pahala bagi yang melaksanakannya dan penanggungan dosa dan sanksi siksa akhir bagi yang meninggalkannya. Oleh sebab itu, zakat perlu dikelola secara kolektif dan memiliki manajemen yang terstruktur melalui amil zakat.

Jika zakat tidak dikelola melalui amil, maka urgensi manfaatnya akan dirasa kurang dan kecenderungannya akan habis untuk sesaat, yakni hal-hal yang bersifat konsumtif yang mana tidak bisa membantu pemberdayaan di bidang pendidikan, kesehatan dan ekonomi. Bukan hanya itu, pembagian bantuan zakat yang tidak merata

\footnotetext{
${ }^{22}$ Muhamad Afif Sholahudin., "Mengapa Pengelolaan Zakat di Indonesia Masih Belum Efektif?", https://www.kompasiana.com/afif114/58c799c1ca23bd3c089ceb66/mengapa-pengelolaanzakat-di-indonesia-masih-belum-efektif (31 Maret 2021).

${ }^{23}$ Paksaan. https://kbbi.web.id/paksa.html (24 April 2020).

${ }^{24}$ Kamus Besar Bahasa Indonesia (KBBI), “Arti Kata Pemaksaan Menurut KBBI”, Situs Resmi Jago Kata. https://jagokata.com (24 April 2020).
} 
ke semua mustahik zakat karena kurangnya pengetahuan masyarakat mengenai wilayah mana saja yang sangat membutuhkan bantuan berupa zakat.

Terdapat rasionalisasi yang kuat mengapa kita harus mengelola zakat melalui amil zakat secara kolektif, bukan karena kepentingan individual, yaitu: ${ }^{25}$

a. Amil berfungsi sebagai intermediasi antara pembayar (muzaki) dan penerima (mustahik).

b. Amil mendorong muzaki untuk menunaikan kewajibannya sekaligus membantu menghitung jumlah kewajiban zakatnya.

c. Amil mampu mengidentifikasi dan mengklasifikasi mustahik secara objektif dan akurat agar penyaluran dan pendayagunaan zakat direalisasikan secara baik dan efektif.

d. Amil dibutuhkan agar muzaki tidak merasa memiliki zakatnya atau penerima zakat, sehingga ketika muzaki merangkap jadi amil, mereka cenderung merasa sebagai pemilik dana dan menempatkan mustahik sebagai peminta dana zakat.

e. Dalam Q.s. At-Taubah/9:60, telah dijelaskan bahwa amil zakat berhak menerima zakat sekalipun mereka orang mampu. Ini menandakan bahwa memang seharusnya ada amil zakat yang mengelola zakat secara profesional dan terstruktur.

f. Muzaki tidak lagi memikirkan kemana zakatnya harus diserahkan.

g. Zakat yang dikelola oleh amil zakat akan didistribusikan dengan tepat sasaran kepada mustahik dan dijadikan pemberdayaan bagi mereka.

Dari keunggulan Amil Zakat yang telah disebutkan tampak tidak akan berjalan sesuai yang diharapkan apabila amil zakat tidak berperan secara profesional dalam menjalankan amanahnya.

\section{Peran Negara dalam Pengelolaan Zakat Umat Islam di Indonesia}

Zakat tidak hanya diperlakukan sebagai pos ritual belaka, akan tetapi zakat memiliki keterkaitan erat dengan kondisi riil masyarakat dalam satu negara ${ }^{26}$. Zakat merupakan salah satu rukun Islam yang landasannya adalah syariat atau hukum Islam. Kedudukan hukum Islam dalam negara Indonesia secara eksplisit tercantum dalam pasal 29 UUD 1945 yang menyatakan bahwa negara berdasarkan atas Ketuhanan Yang Maha Esa dan menjamin kemerdekaan masing-masing penduduk untuk melaksanakan ibadah berdasarkan agama dan kepercayaannya ${ }^{27}$.

Menurut Muhammad Daud Ali, hukum Islam di negara Indonesia berlaku secara Normatif dan formal Yuridis. Hukum Islam yang berlaku secara normatif adalah bagian dari hokum Islam yang mempunyai sanksi kemasyarakatan apabila norma-normanya dilanggar. Kuat tidaknya sanksi kemasyarakatan yang dimaksud tergantung pada kuat lemahnya kesadaran umat Islam akan norma-norma hukum Islam yang bersifat normatif itu. Hukum Islam yang berlaku secara normatif di Indonesia seperti pelaksanaan ibadah puasa, zakat dan haji. Hampir semua hukum Islam yang mengatur hubungan manusia

\footnotetext{
${ }^{25}$ Muhammad Daud Ali, Sistem Ekonomi Islam Zakat dan Wakaf (UI Press: Jakarta, 1988), 52.

${ }^{26}$ Ali Ridho, "Zakat dalam Persfektif Ekonomi Islam”, Ekonomi Islam 7. no.1 (2014), 123.

${ }^{27}$ Chusainul Adib, Peran Negara dalam Pengelolaan Zakat Ummat Islam di Indonesia (t.d), 13-

14.
} 


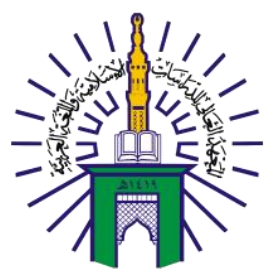

\section{BUSTANUL FUQAHA: \\ JURNAL BIDANG HUKUM ISLAM \\ Vol. 2 No. 1 (2021): Hal. 78-97 \\ EISSN: 2723-6021 \\ Website: https://journal.stiba.ac.id}

dengan Tuhan bersifat normatif ${ }^{28}$. Adapun hukum Islam yang berlaku secara formal yuridis adalah bagian hukum Islam yang mengatur hubungan manusia dengan manusia lain dan benda dalam masyarakat. Bagian hukum Islam ini menjadi bagian hukum positif berdasarkan atau karena ditinjau oleh peraturan perundang-undangan, seperti misalnya hukum perkawinan, hukum kewarisan, dan hukum wakaf ${ }^{29}$.

Dengan dituangkannya hukum Islam dalam bentuk Undang-Undang, maka pemberlakuannya tidak lagi hanya didasarkan pada kesadaran iman dan takwa umat Islam, melainkan juga atas dasar kekuatan hukum atau peraturan perundang-undangan yang berlaku. Bagaimana negara mengakomodasi hukum Islam? Pasal 29 UUD 1945 yang menyatakan bahwa negara berdasarkan atas Ketuhanan Yang Maha Esa dan menjamin kemerdekaan masing-masing penduduk untuk melaksanakan ibadah berdasarkan agama dan kepercayaanya. Menurut Hazairin, kaidah fundamental tersebut dapat ditafsirkan sebagai berikut: ${ }^{30}$

a. Dalam Negara Republik Indonesia tidak boleh ada atau tidak boleh berlaku hukum yang bertentangan dengan kaidah-kaidah agama yang berlaku bagi pemeluk agama.

b. Negara wajib menjalankan syariat semua agama yang berlaku di Indonesia, dalam makna memberikan fasilitas agar hukum yang berasal dari agama dipeluk bangsa Indonesia dapat terlaksana. Untuk menjalankan syariat itu, maka diperlukan bantuan kekuasaan negara atau penyelenggara negara.

c. Syariat tidak memerlukan bantuan kekuasaan negara untuk melaksanakannya karena dapat dijalankan sendiri oleh setiap pemeluk agama yang bersangkutan. Selain itu, hal ini telah menjadi kewajiban pribadi pemeluk agama itu sendiri dan menjalanknnya menurut agamanya masing-masing.

Pasal 29 UUD 1945 sendiri mempunyai tiga muatan makna. Salah satunya, negara berkewajiban membuat peraturan perundang-undangan atau melakukan kebijakan-kebijakan bagi pelaksanaan wujud rasa keimanan kepada Tuhan Yang Maha $\mathrm{Esa}^{31}$. Adapun dari makna yang telah disebutkan, dapat dipahami bahwa negara berkewajiban secara aktif melakukan upaya-upaya agar setiap penduduk dapat memeluk agama dan beribadah menurut agama dan kepercayaannya.

Salah satu upaya yang harus dilakukan pemerintah adalah perhatiannya terhadap zakat. Masalah zakat selama ini dipandang sebagai ibadah yang banyak tergantung kepada individu muslim pada pelaksanaannya. Tetapi karena menyangkut kepentingan banyak orang, maka ibadah ini pada waktu sekarang telah memasuki cakupan muamalat. Artinya bahwa zakat sangat berpengaruh terhadap hubungan antara satu orang dengan yang lainnya. Untuk itu, perlu ada aturan khusus dan undang-undang yang dapat menjamin pelaksanaanya sehingga tidak ada hak-hak orang lain yang dilalaikan.

\footnotetext{
${ }^{28}$ Muhammad Daud Ali, Hukum Islam Pengantar Hukum Islam dan Tata Hukum Islam di Indonesia (Jakarta: Raja Grafindo Persada, 2002), 5-6.

${ }^{29}$ Muhammad Daud Ali, Hukum Islam Pengantar Hukum Islam dan Tata Hukum Islam di Indonesia, h. 6.

${ }^{30}$ Muḥammad Daud Ali, Hukum Islam Pengantar Hukum Islam dan Tata Hukum Islam di Indonesia, 7-8.

${ }^{31}$ Hartono Mardjono, Menegakkan Syari'at Islam dalam Konteks Keindonesiaan (Bandung: Mizan, 1997), 18.
} 

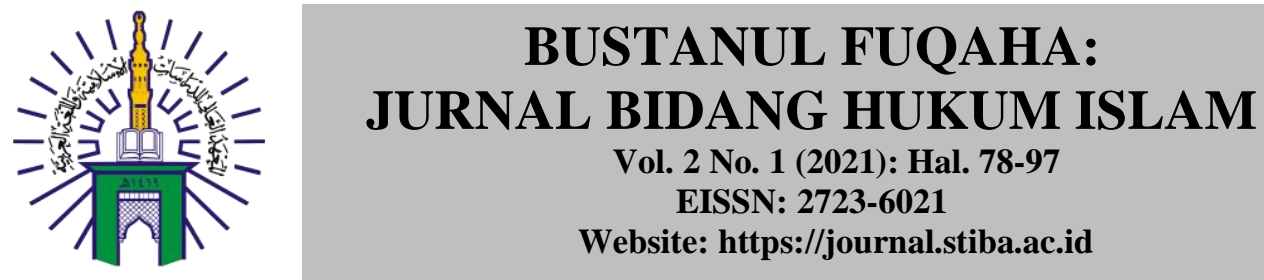

Pada Pasal 34 Undang-undang Dasar 1945 Ayat (1), dinyatakan bahwa fakir miskin dan anak-anak terlantar dipelihara oleh negara. Kemudian dalam ayat (2) dinyatakan bahwa negara mengembangkan sistem jaringan sosial bagi seluruh rakyat dan memberdayakan masyarakat yang lemah dan tidak mampu sesuai dengan martabat kemanusiaan. Dengan demikian, negara mempunyai kewajiban untuk memelihara fakir miskin dan anak terlantar serta melakukan pemberdayaan kepada mereka melalui sistem jaringan sosial, artinya bahwa negara bekerjasama dengan elemen masyarakat dalam kesejahteraan mereka.

Salah satu cara pemberdayaan yang paling efektif adalah melalui zakat bagi kalangan umat Islam. Meskipun sampai saat ini belum ada paksaan dari pemerintah untuk memungut zakat, namun pengelolaan zakat pemerintah telah mengatur dalam bentuk undang-undang dengan pertimbangan: Pertama, bahwa zakat merupakan kewajiban bagi umat Islam yang mampu sesuai dengan syariat Islam; Kedua, bahwa zakat merupakan pranata keagamaan yang bertujuan untuk meningkatkan keadilan dan kesejahteraan masyarakat; Ketiga, bahwa dalam rangka meningkatkan daya guna dan hasil guna, zakat harus dikelola secara melembaga sesuai dengan syariat Islam, dan hal ini diatur dalam UU no. 23 tahun 2011 tentang pengelolaan zakat ${ }^{32}$. Dengan demikian, dalam hal pelaksanaan zakat di Indonesia, negara tidak memaksa karena pelaksanaan zakat di Indonesia masih bersifat sukarela.

Di samping itu, negara Indonesia bukanlah negara agama atau negara Islam, di mana syariat Islam dijadikan sebagai landasan konstitusi negara, melainkan negara demokrasi yang dijadikan nilai-nilai keagamaan sebagai landasan konstitusi. Zakat juga tidak masuk dalam sistem keuangan negara. Namun, negara tidak menafikan peran zakat yang sejalan dengan tujuan diselenggarakannya negara yaitu memajukan kesejahteraan umum dan mencerdaskan kehidupan bangsa. Oleh sebab itu, negara memberikan insentif fiskal bagi pembayar zakat (muzaki) dengan menjadikan zakat sebagai pengurang Penghasilan Kena Pajak (PKP) salah satunya di daerah Kabupaten Gowa menerapkan kebijakan pemerintah tersebut ${ }^{33}$. Hal ini dilakukan supaya wajib pajak tidak terkena beban ganda, yaitu kewajiban membayar zakat dan pajak. Dengan demikian, kesadaran membayar zakat dapat memacu masyarakat lain untuk membayar pajak.

Negara dalam hal pengelolaan zakat di Indonesia juga berperan sebagai regulator, pembina, pengawas, dan sekaligus sebagai pengelola. Sebagai regulator, negara membuat peraturan perundang-undangan dan peraturan-peraturan pelaksana di bawah undang-undang yang mengatur tentang pengelolaan zakat. Dalam hal ini negara telah mengeluarkan UU No. 23 Tahun 2011 dan Lembaga Badan Amil Zakat Nasional (BAZNAS) serta lembaga-lembaga kecil di setiap daerah yaitu Lembaga Amil Zakat (LAZ) dan Badan Amil Zakat (BAZ).

Adapun tujuan dari dibentuknya undang-undang dan lembaga pengelolaan zakat, sebagai berikut:

\footnotetext{
${ }^{32}$ Konsideran Undang-Undang Nomor 23 Tahun 2011 Tentang Pengelolaan Zakat.

${ }^{33}$ Rafiqah Aliyati, "Penerapan Zakat Sebagai Pengurang Penghasilan Kena Pajak di Kantor Kementrian Agama Kabupaten", Skripsi (Makassar: Fak. Ekonomi dan Bisnis Islam UIN Alauddin, 2015), 76.
} 
1. Pengelolaan Zakat Menurut Undang-undang No. 23 Tahun 2011, menurut Undang-undang RI No. 23 Tahun 2011, pengertian, asas dan tujuan pengelolaan zakat adalah sebagai berikut: ${ }^{34}$

a. Pengertian pengelolaan zakat adalah kegiatan perencanaan, pelaksanaan dan pengoordinasian dalam pengumpulan, pendistribusian dan pendayagunaan zakat.

b. Pengelolaan zakat berasaskan syariat Islam, amanah, pemanfaatan, keadilan, kepastian hukum, terintegrasi, dan akuntabilitas.

c. Pengelolaan zakat bertujuan untuk meningkatkan efektivitas dan efisiensi pelayanan dalam pengelolaan zakat, serta meningkatkan manfaat zakat untuk mewujudkan kesejahteraan masyarakat dan penanggulangan kemiskinan.

Dari ketiga tujuan pengelolaan zakat, maka akan dapat tercapai apabila pemerintah Indonesia memberikan perhatian khusus terhadap lembaga pengelolaan zakat dalam menghimpun segala bentuk harta yang wajib dizakati.

\section{Organisasi dan Peran Lembaga Pengelolaan Zakat BAZNAS (Badan Amil Zakat Nasional)}

BAZNAS terdiri dari unsur pemerintah yang mana BAZNAS provinsi dibentuk oleh menteri atas usul Gubernur setelah mendapat pertimbangan BAZNAS. Badan Amil Zakat Nasional (BAZNAS) merupakan badan resmi dan satu-satunya dibentuk oleh pemerintah berdasarkan Keputusan Presiden RI No. 8 tahun 2001. Selain itu, ia juga memiliki tugas dan fungsi menghimpun dan menyalurkan zakat infak, dan sedekah (ZIS) pada tingkat nasional. Lahirnya Undang-undang Nomor 23 tahun 2011 tentang pengelolaan zakat semakin mengukuhkan peran BAZNAS sebagai lembaga yang berwenang melakukan pengelolaan zakat secara nasional.

BAZNAS mempunyai empat fungsi dalam menjalankan tugasnya yaitu perencanaan, pengumpulan, pendistribusian dan pendayagunaan zakat. Untuk terlaksananya tugas dan fungsi tersebut, maka BAZNAS memiliki kewenangan untuk memberikan rekomendasi dalam pembentukan Badan Amil Zakat Nasional (BAZNAS) Provinsi dan Badan Amil Zakat Nasional (BAZNAS) kabupaten/kota dan pembentukan Lembaga Amil Zakat di setiap desa untuk membantu BAZNAS sehingga mudah dalam pengontrolan zakat ${ }^{35}$. Selain itu, BAZNAS merupakan lembaga pemerintah nonstruktural yang bersifat mandiri dan bertanggung jawab kepada Presiden melalui menteri yang menyelenggarakan urusan pemerintahan di bidang agama, yakni menteri agama. BAZNAS juga merupakan lembaga yang berwenang melakukan tugas pengelolaan zakat secara nasional, dan memiliki kewenangan untuk mengkoordinasi Badan Amil Zakat (BAZ) dan Lembaga Amil Zakat (LAZ), membangun sistem informasi pengelolaan zakat yang terintegrasi secara nasional, membuat peta potensi penghimpunan dan penyaluran zakat, serta membangun basis data muzaki dan mustahik zakat nasional.

${ }^{34}$ Dewan Perwakilan Rakyat dan Presiden, Undang-Undang Republik Indonesia Nomor 23 Tahun 2011, Tentang Pengelolaan Zakat (Jakarta: Departemen Agama Republik Indonesia, t.th), 1-2.

${ }^{35}$ Siti Aminah Chaniago, "Jurnal Hukum Islam", Pemberdayaan Zakat Produktif dalam Pemberantasan Kemiskinan 10, no. 2 (2012), 253-254. 


\section{LAZ (Lembaga Amil Zakat)}

LAZ yang dikelola oleh masyarakat yang dibina, dilindungi dan dikukuhkan oleh pemerintah. BAZNAS maupun LAZ kepengurusannya terdiri dari badan pertimbagan, pengawas, dan pelaksana. Lembaga Amil Zakat (LAZ) yang beroperasi tanpa izin dari pejabat yang berwenang terancam pidana penjara maksimal satu tahun atau dipidana denda maksimal 50 juta rupiah ${ }^{36}$. Hal ini ditujukan agar Lembaga Amil Zakat (LAZ) tidak menyimpang dari tujuan semula dan menjamin kepastian hukum Lembaga Amil Zakat (LAZ).

\section{UPZ (Unit Pengumpul Zakat)}

UPZ dibentuk oleh BAZNAS provinsi dan BAZNAS kabupaten/kota pada instansi Pemerintah, BUMN, BUMD, Perusahaan Swasta dan lain sebagainya ${ }^{37}$. Dalam pengelolaan zakat, yang bertugas mengelolanya adalah seorang amil. Tugas mereka bukan hanya menghimpun zakat dan memprosesnya, akan tetapi juga berkewajiban mendistribusikannya. UPZ juga bertugas mengadakan sosialisasi kepada muzaki atau masyarakat tentang pentingnya membayar zakat. Selain itu, juga bertugas mengarahkan dan memberikan pembinaan kepada fakir miskin yang menerima zakat. Hal ini diharapkan agar zakat yang diterimanya bukan hanya untuk dikonsumsi tetapi bagaimana agar mereka bisa memberdayakan bantuan tersebut untuk mengangkat perekonomian mereka. Amil zakat pun juga diharapkan bisa ikut serta dalam memberdayakan zakat secara benar dan tepat.

\section{Asas Pengelolaan Zakat}

Asas pengelolaan zakat untuk meningkatkan efektivitas dan efisiensi pelayanan dalam pengelolaan zakat dan meningkatkan manfaat masyarakat serta penanggulangan kemiskinan, maka pengelolaan zakat dapat berasaskan ${ }^{38}$, yakni:

1) Berasaskan syariat Islam. Yakni, pengelolaan zakat dimulai dari penghimpunan, pendistribusian, dan pendayagunaan zakat harus dilaksanakan sesuai dengan syariat Islam.

2) Kemanfaatan. Yakni, pengelolaan zakat dilakukan untuk memberikan manfaat yang sebesar-besarnya kepada mustahik.

3) Keadilan. Yakni, pendistribusian zakat dilakukan secara adil.

4) Kepastian hukum. Yakni, dalam pengelolaan zakat terdapat kepastian hukum bagi mustahik dan muzaki.

5) Terintegrasi. Yakni, pengelolaan zakat dilaksanakan secara hierarkis dalam upaya meningkatkan pengumpulan, pendistribusian dan pendayagunaan zakat.

6) Akuntabilitas. Yakni, pengelolaan zakat dapat dipertanggungjawabkan dan diakses oleh masyarakat.

\section{Peran Negara terhadap Pengelolaan Zakat}

Ada beberapa hal yang harus dilakukan oleh pemerintah untuk mengoptimalkan potensi zakat agar dapat berjalan dengan lancar dan maksimal sesuai yang diharapkan, yaitu:

\footnotetext{
${ }^{36}$ Dewan Perwakilan Rakyat dan Presiden, Undang-Undang Republik Indonesia Nomor 23 Tahun 2011, Tentang Pengelolaan Zakat Pasal 31 dan Pasal 38, h.7-8.

${ }^{37}$ Saifuddin Zuhri, Zakat di Era Reformasi (Semarang: Bima Sejati, 2012), 153.

${ }^{38}$ Dewan Perwakilan Rakyat dan Presiden, Undang-Undang Republik Indonesia Nomor 23 Tahun 2011, Tentang Pengelolaan Zakat Pasal 2, h. 2.
} 


\section{1) Penyadaran}

Penyadaran masyarakat akan kewajiban menunaikan zakat merupakan aspek penting yang harus dilakukan oleh sebuah lembaga pengelola zakat. Diharapkan dengan sadarnya masyarakat akan kewajiban mereka dalam menunaikan zakat akan menambah income atau pemasukan bagi lembaga pengelola zakat. Dengan adanya penambahan dana zakat ini, tentunya semakin bertambah pula orang-orang yang dapat dibantu untuk mengangkat ke derajat perekonomian yang lebih mapan. Penyadaran dapat dilakukan dengan dua hal, yaitu: Pertama, busyrā atau kabar gembira, dengan busyrā ini kita berikan kabar gembira kepada masyarakat tentang keutamaan zakat. Kedua, peringatan, dengan peringatan ini diharapkan masyarakat akan menjadi sadar bahwa akan merugi orang-orang yang selalu melalaikan zakat baik di dunia maupun di akhirat.

\section{2) Kepercayaan}

Kepercayaan masyarakat terhadap lembaga-lembaga zakat yang telah dibentuk oleh pemerintah adalah sesuatu yang asasi yang harus dimiliki. Hal ini dikarenakan kepercayaan dari masyarakat bahwa Lembaga Amil Zakat dapat menjalankan programprogramnya. Oleh karenanya, jangan sekali-kali mengkhianati kepercayaan yang telah diberikan masyarakat. Sekali masyarakat sudah tidak percaya, maka dampaknya akan sangat besar sekali bagi pengoptimalan dana zakat. Dampaknya bukan hanya kepada LAZ yang mengkhianati kepercayaan masyarakat.

\section{3) Amanah}

Amanah berarti bertanggung jawab dengan apa yang telah ditugaskan dengan menjalankannya dengan baik sesuai dengan prosedur yang ada. Sifat amanah merupakan inti dari kepercayaan.

a) Profesionalisme. Bersikap profesional dalam kinerja, profesional dalam pelayanan, profesional dalam keilmuan atau wawasan tentang zakat. Mulai dari seluk beluk zakat, seperti syarat wajib zakat, hukum zakat, harta yang wajib dizakati, nisab dan haul zakat, sumber zakat terdahulu dan sekarang serta ke mana zakat akan didistribusikan.

b) Transparan. Transparan yaitu adanya keterbukaan dari pihak LAZ/BAZ akan segala hal yang ada di lembaga tersebut. Khususnya tentang keuangan zakat dan penyalurannya dengan memublikasikannya kepada masyarakat. Caranya baik melalui media massa ataupun media-media promo yang dimiliki oleh lembaga.

\section{4) Sosialisasi}

Sosialisasi merupakan aspek penting yang mutlak harus dimiliki oleh sebuah LAZ/BAZ, karena tanpa adanya sosialisasi, maka tidak mungkin masyarakat akan tahu eksistensi zakat dan eksistensi lembaga pengelolaan zakat. Adapun langkah-langkah yang dilakukan dalam melakukan sosialisasi, yaitu:

a) Sosialisasi tentang zakat itu sendiri. Sebagaimana yang kita ketahui bahwa masyarakat masih banyak yang awam tentang seluk beluk zakat.

b) Sosialisasi lembaga pengelolaan zakat. Sebuah lembaga harus menyosialisasikan dirinya supaya bisa dikenal di masyarakat. Semakin banyak masyarakat yang mengenalnya, maka semakin banyak pula masyarakat yang menyalurkan zakat kepada lembaga yang dikenalnya. Adapun yang harus kita perhatikan bahwa menyalurkan zakat melalui lembaga pengelola zakat akan 
jauh lebih efektif dibandingkan menyalurkannya secara orang perorangan. Ada beberapa keuntungan yang bisa didapatkan dengan menyalurkan zakat kepada lembaga pengelolaan zakat yang tidak akan diperoleh dengan membayar secara langsung oleh muzaki kepada mustahik, yaitu:

1) Menjamin kepastian dan disiplin muzaki dalam membayar zakat.

2) Untuk menjaga perasaan rendah diri para mustahik.

3) Memperlihatkan syiar Islam.

4) Untuk mencapai efisiensi dan efektivitas serta sasaran yang tepat dalam penggunaan dana zakat menurut skala prioritas.

5) Dapat digunakan untuk kemaslahatan umat Islam secara umum yang memerlukan dana yang tidak sedikit.

c) Sosialisasi program. Sosialisasi program dan layanan yang ada di lembaga tersebut supaya masyarakat dapat mengetahui, sehingga masyarakat akan memanfaatkan program-program atau layanan-layanan yang ada di lembaga tersebut. Untuk itu, sebelum mengadakan sosialisasi, maka harus dipastikan bahwa layanan-layanan tersebut telah tersosialisasi dengan baik.

\section{5) Pemahaman}

Apabila masyarakat telah sadar bahwa zakat itu merupakan kewajiban yang harus ditunaikan dan mereka sadar bahwa dalam harta mereka terdapat hak-hak fakir miskin dan orang-orang yang membutuhkan, juga mereka percaya dengan lembaga pengelola zakat yang ada. Mereka juga tahu bahwa ada kewajiban zakat yang harus mereka tunaikan selain zakat fitrah. Oleh karena itu, lembaga pengelola zakat harus memberikan pemahaman kepada masyarakat tentang tata cara perhitungan dan prosedur pengeluaran zakat. Ada masyarakat yang sudah sadar akan kewajiban zakat namun belum mengetahui tata cara perhitungan dan prosedur zakat.

\section{Pemaksaan Zakat dalam Perspektif Hukum Islam}

Zakat merupakan pengalihan harta dari orang yang mampu kepada orang yang membutuhkan tanpa mengharapkan imbalan, semata-mata hanya mengharapkan rida dan pahala dari Allah swt. Zakat sebagai salah satu rukun Islam yang secara tegas diperintahkan oleh Allah swt. dalam banyak firmannya. Salah satunya dalam Q.s. AlBaqarah/2:43, yang memerintahkan untuk menunaikan zakat. Dari kata "Tunaikanlah zakat", artinya bahwa Allah swt. mewajibkan hamba-Nya untuk menunaikan zakat, baik zakat fitrah maupun zakat harta. Setelah Allah swt. mewajibkan untuk mengumpulkan zakat, maka Allah jugalah yang memerintahkan untuk dikelola oleh Amil Zakat secara kolektif sebagaimana firman-Nya dalam Q.s. At-Taubah/9:103, yang memerintahkan penguasa untuk mengambil zakat dari kaumnya. Sebagaimana yang telah terjadi di zaman Rasulullah saw., sahabat dan tabiin hingga para pemimpin Islam.

Setelah Allah swt. memerintahkan untuk menunaikan zakat dan para penguasa diperintahkan untuk mengambil zakat dari kaumnya, maka Allah swt. memerintahkan untuk memberikan bagian zakat untuk Amil Zakat sebagaimana dalam Q.s. AtTaubah/9:60. Semua ini menandakan bahwa Allah swt. memang menganjurkan adanya suatu lembaga yang dikhususkan untuk mengelola zakat dan muzaki berhak untuk mengumpulkan zakatnya ke lembaga tersebut. Para fuqaha' secara umum bersepakat bahwa penguasa baik itu pemimpin atau pemerintah wajib mengangkat dan mengirim 
petugas untuk memungut zakat ${ }^{39}$. Hal ini dikarenakan di masyarakat banyak rakyat yang belum memahami akan wajibnya zakat, kapan dikatakan wajib zakat, berapa jumlah zakat yang harus dikeluarkan, ke mana zakat akan didistribusikan atau ada yang telah mengetahui segala hukum mengenai zakat namun belum melaksanakannya karena tidak adanya kontrol dari pemerintah atau adanya sifat kikir yang dimilikinya.

Jumhur ulama sepakat bahwa perintah خَذْ مِنْ أَمْوَ الِكِْْ (khuż min amwālihim) dalam Q.s. At-Taubah/9:103, artinya bahwa, ambillah zakat dari sebagian harta mereka. perintah ini ditujukan kepada Nabi Muhammad dan kepada setiap pemimpin yang mengurus urusan kaum muslimin sesudahnya. Kasus perang Riddah yaitu perang melawan para pembangkang di zaman khalifah Abu Bakar As-Siddiq yang meluruskan kesalahan penafsiran terhadap Q.s. At-Taubah/9:103, dan mengatakan bahwa pengumpulan zakat hanyalah kewenangan persoalan nabi. Selain itu, perintah مَذْ مِنْ أَمْوَ الِِهْْ (khuz min amwālihim) dalam Q.s. At-Taubah/9:103 ini, konteksnya ialah diterimanya taubat para sahabat yang tidak ikut dalam Perang Tabuk bersama Nabi Muhammad disebabkan oleh cintanya mereka pada harta benda yang mereka miliki. Setelah Allah menerima taubat mereka, mereka kemudian membawa harta bendanya kepada nabi dan berkata, "Wahai Rasulullah, ini harta benda kami. Tolong wakili kami menyedekahkannya dan mintakan ampun untuk kami." Nabi Menjawab, "Aku tidak diperintahkan mengambil sedikitpun harta kalian." Berdasarkan kisah ini, maka turunlah Al-Qura'n surat At-Taubah/9:103 ${ }^{40}$.

Jumhur ulama sepakat bahwa pengelolaan zakat al-Amwāl al-Zāhirah (harta benda yang tampak) seperti binatang ternak dan hasil bumi merupakan kewenangan penuh penguasa/pemerintah, di mana penguasa/pemerintah berhak memungutnya ${ }^{41}$. AlQardhawi memilih dan menguatkan dua pendapat tentang pengelolaan zakat dalam fikih Islam. Pertama, pengelolaan zakat bagian merupakan bagian dari otoritas pemerintah muslim, di mana pemerintah berhak mengumpulkan zakat dari seluruh jenis harta, baik zahir maupun batin, terutama jika penguasa mengetahui bahwa rakyatnya melalaikan kewajiban zakat. Kedua, kegagalan pemerintah mengelola zakat dengan membiarkan dan tidak memungut zakat dari masyarakat tidak menghapus tanggung jawab individu dari pembayaran zakat, di mana muzaki tetap harus menilai zakat yang harus dibayarnya dan menyalurkannya sendiri kepada mustahik ${ }^{42}$.

Wacana pengelolaan zakat oleh penguasa ini tidak lepas dari perbedaan dan dinamika sosial. Di mana penyerahan zakat kepada penguasa/pemerintah pertama kali setelah terbunuhnya Usman bin Affan. Lalu di zaman Umar bin Khattab, zakat mulai disebarkan ke luar daerah di wilayah zakat dipungut dengan memperhatikan kriteria mustahik dan diprioritaskan kepada kaum fakir miskin ${ }^{43}$. Adapun di zaman Ibnu Umar sangat tegas menyatakan bahwa zakat wajib diserahkan kepada penguasa sekalipun

\footnotetext{
${ }^{39}$ Chusainul Adib, Peran Negara dalam Pengelolaan Zakat Ummat Islam di Indonesia, 10.

${ }^{40}$ Muḥammad Nawawai bin Umar al-Jawi, at-Tafsir al-Nawawi (Juz. 1.Surabaya: al-Hidayah t.th.), 353

${ }^{41} \mathrm{Abu}$ 'Ubaid al-Qasim, al-Amwāl: Ensiklopedia Keuangan Publik (t.t: Gema Insani, 2009), 111.

${ }^{42}$ Yusuf Wibisono, Mengelola Zakat Indonesia (Cet. 2; Jakarta: Kencana, 2016), 144.

${ }^{43}$ Azwar Iskandar, and Khaerul Aqbar, "ZAKAT DISTRIBUTION POLICY OF UMAR BIN KHATTAB AND COVID-19 CRISIS," Tasharruf: Journal Economics and Business of Islam 5, no. 2 (2020), 160-178.
} 
mereka tidak lagi memiliki komitmen keagamaan. Sepanjang para penguasa itu muslim (masih menunaikan salat), maka masyarakat wajib menyerahkan zakat ke penguasa. Namun, setelah mengikuti dinamika yang ada di masyarakat, Ibnu Umar akhirnya mengubah pendapatnya dengan tidak mewajibkan lagi masyarakat ke penguasa tetapi mendistribuskannya secara langsung kepada mereka yang berhak yaitu mustahik zakat $^{44}$.

Hal ini secara jelas mengindikasikan bahwa ketika para ulama menegaskan kewajiban menyerahkan zakat ke penguasa, mereka mengasumsikan bahwa pemerintah berkarakter Islam. Ketika komitmen keagamaan penguasa mengalami degradasi secara signifikan, maka mereka tidak lagi mewajibkan dimensi politik zakat, tetapi tetap menjalankan dimensi ritualnya, yaitu mendistribusikan zakat secara langsung kepada mustahik. Dinamika fikih ini menegaskan bahwa karakter zakat sebagai institusi keuangan publik yang bersifat khusus, yaitu bahwa zakat harus didistribusikan kepada publik, baik melalui pemerintah ataupun tidak. Aspek distributif zakat jauh lebih penting daripada aspek pengumpulannya ${ }^{45}$. Dengan demikian, tujuan utama pengelolaan zakat yaitu tersampaikannya zakat kepada mustahik secara merata, tepat sasaran dan kemanfaatan yang lebih optimal sehingga dibutuhkan amil zakat. Kesimpulan ini selaras dengan kaidah fikih kontemporer al-i'brah bimaqāșid al-syaria'h (pelajaran harus mengacu pada tujuan syariat). Artinya bahwa keberadaan Amil Zakat di Indonesia akan memudahkan masyarakat menyalurkan zakatnya, adanya motivasi dari setiap masyarakat untuk mengeluarkan zakat karena pemungutan zakat dilakukan secara merata, adanya pengelolaan zakat yang terstruktur dan memudahkan muzaki menyalurkan zakatnya kepada mustahik. Namun, bukan berarti adanya Amil Zakat mewajibkan masyarakat harus menyerahkan zakatnya kepada penguasa namun apabila muzaki ingin menyalurkan zakatnya kepada mustahik pilihannya maka itu lebih baik.

Ada dua hikmah penting yang dapat kita petik dalam pengelolaan zakat oleh pemerintah di Indonesia, yaitu: Pertama, terhindarnya mustahik dari aib meminta-minta kepada muzaki. Dengan adanya pengelolaan zakat dari pemerintah Indonesia, maka para mustahik tidak perlu lagi pergi meminta-minta kepada muzaki karena mereka langsung menerima zakat dari pemerintah. Kedua, terhindarnya fakir miskin dari rasa rendah diri, iri hati dan negative thinking kepada muzaki serta dengan adanya zakat yang dikelola oleh pemerintah Indonesia maka peluang lapangan kerja semakin banyak karena mustahik yang mendapat zakat akan dibina dan diarahkan dalam mengelola zakat tersebut. Adapun satu-satunya lembaga yang mempunyai otoritas untuk melakukan pemaksaan seperti itu adalah negara lewat perangkat pemerintahan di Indonesia. Dengan demikian, zakat dapat disalurkan secara tepat, efisien dan efektif profesional untuk mencapai tujuan zakat itu sendiri yaitu meningkatkan taraf hidup masyarakat agar menjadi rukun, makmur, sejahtera, dan tercipta keadilan bagi seluruh rakyat di Indonesia.

Seiring dengan dibentuknya LAZ dan BAZ oleh pemerintah Indonesia di seluruh wilayah Indonesia, maka pemerintah wajib mengelola zakat berdasarkan ketentuan

\footnotetext{
${ }^{44}$ Chusainul Adib, Peran Negara dalam Pengelolaan Zakat Ummat Islam di Indonesia, (t.d), 13.

${ }^{45}$ Ugi Suharto, Keuangan Publik Islam: Reinterpretasi Zakat dan Pajak (Yogyakarta: Sekolah Tinggi Ilmu Syari’ah Yogyakarta, 2004 ),199-200.
} 


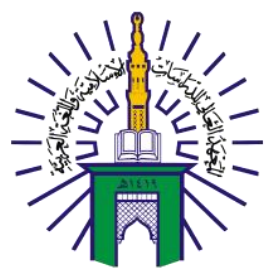

\section{BUSTANUL FUQAHA: \\ JURNAL BIDANG HUKUM ISLAM \\ Vol. 2 No. 1 (2021): Hal. 78-97 \\ EISSN: 2723-6021 \\ Website: https://journal.stiba.ac.id}

syariat Islam, yaitu mengikuti perintah Allah, Rasul-Nya dan Ulil Amri di Indonesia. Sebagaimana firman Allah dalam Q.s. An-Nisa/4:59. Oleh karena itu, tidak sewajarnya pemerintah Indonesia yang memegang kendali dalam penyaluran zakat menyalahgunakan pemanfaatan zakat. Apabila dalam pengelolaan zakat didapati pemerintah yang memegang kekuasaan terhadap pengelolaan zakat tidak mengelola zakat sesuai ketentuan syariat maka masyarakat muslim Indonesia tidak berhak bahkan tidak boleh menyalurkan zakatnya kepada pemerintah Indonesia melalui badan amil zakat yag telah dibentuknya.

\section{KESIMPULAN}

Pengelolaan zakat pada zaman Rasulullah dan khulafaurasyidin dilakukan dengan penuh tanggung jawab sesuai dengan tuntunan syariat. Struktur zakat dimulai dengan pendirian Baitul Mal yang difungsikan sebagai tempat mengelola sumbersumber keuangan termasuk pengelolaan zakat. Adapun dari sistem pemaksaan zakat di Indonesia, maka langkah-langkah kebijakan yang harus diambil oleh pemerintah dalam pengelolan zakat adalah secara kolektif dan/atau memiliki manajemen zakat yang terstruktur dan tersistematis. Untuk itu, maka sistem yang harus dilakukan oleh pemerintah untuk melakukan pemungutan zakat secara paksa di antaranya: Pertama, beban pajak yang ditanggung oleh muzaki dikurangi dengan jumlah zakat yang telah dikeluarkan; Kedua, menyadarkan masyarakat akan kewajiban menunaikan zakat; Ketiga, membuat masyarakat percaya terhadap lembaga-lembaga zakat yang telah di bentuk; Keempat, melakukan sosialisasi untuk memahamkan eksistensi zakat dan eksistensi lembaga pengelolaan zakat; Kelima, memberikan pemahaman kepada masyarakat tentang tata cara perhitungan dan prosedur pengeluaran zakat; Keenam, memberikan sanksi yang tegas bagi yang melakukan pelanggaran, baik melanggar kewajiban zakat ataupun pajak. Dalam pengelolaan zakat, negara berperan sebagai regulator, pengelola dan pengawas.

Pemaksaan zakat dalam perspektif hukum Islam sangat dianjurkan. Para fuqaha' secara umum bersepakat bahwa penguasa baik itu pemimpin atau pemerintah wajib mengangkat dan mengirim petugas untuk memungut zakat. Jumhur ulama sepakat bahwa perintah خَذْ مِنْ أَمْوَ الِهِخْ (khuż min amwālihim) dalam Q.s. At-Taubah/9:103, artinya bahwa, ambillah zakat dari sebagian harta mereka. Perintah ini ditujukan kepada Nabi Muhammad dan kepada setiap pemimpin yang mengurus urusan kaum muslimin sesudahnya.

Berdasarkan kesimpulan di atas, maka implikasi dari penelitian ini, yaitu:

1. Peran negara sebagai regulator hendaknya merevisi UU no. 23 tahun 2011 tentang pengelolaan zakat, menerapkan sistem pengurangan pajak terhadap zakat sehingga zakat wajib atas kaum muslimin dan pajak wajib atas masyarakat non-muslim serta menetapkan sanksi bagi yang melanggar.

2. Hendaknya negara membentuk Badan Amil Zakat mulai dari pusat hingga desa untuk memudahkan pemungutan zakat, pengelolaan dan transparan pendistribusian zakat bagi masyarakat sehingga mereka bisa melihat hasil dari zakat yang mereka serahkan ke Badan Amil Zakat. 


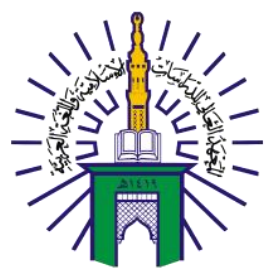

BUSTANUL FUQAHA:

JURNAL BIDANG HUKUM ISLAM

Vol. 2 No. 1 (2021): Hal. 78-97

EISSN: 2723-6021

Website: https://journal.stiba.ac.id

\section{DAFTAR PUSTAKA}

Adib, Chusainul. "Peran Negara dalam Pengelolaan Zakat Umat Islam di Indonesia." Jurnal Nestor Magister Hukum 1, no. 1 (2017) : 1-27.

Ali, Muhammad Daud. Hukum Islam Pengantar Hukum Islam dan Tata Hukum Islam di Indonesia. Jakarta: Raja Grafindo Persada, 2002.

Ali, Muhammad Daud. Sistem Ekonomi Islam Zakat dan Wakaf. Jakarta: UI Press, 1988.

Aliyati, Rafiqah. Penerapan Zakat Sebagai Pengurang Penghasilan Kena Pajak di Kantor Kementrian Agama Kabupaten. Makassar: Skripsi, Fak. Ekonomi dan Bisnis Islam UIN Alauddin, 2015.

Al-Faifi, Sulaimān bin Aḥmad bin Yahyā. al-Wajīz fì-Fiqh al-Sunnah. Cet. IV; Lebanon: Beirut Publishing, 2018.

Al-Jawi, Muhammad Nawawi bin Umar. Al-Tafsir Al-Nawawi. Juz. 1. Surabaya: AlHidayah, t.th.

Al-Qaḥțānī, Sa'̄̄d bin Alī bin Wahab. al-Zakāh fì al-Islām fì Daui Kitab wa al-Sunnah. Saudi Arabia: Maktab al-Da'wah bil-Qașbi, 2010.

Al-Qasim, Abu 'Ubaid. Al-Amwāl: Ensiklopedia Keuangan Publik. t.t: Gema Insani, 2009.

Aqbar, K., \& Iskandar, A. "Kontekstualisasi Ekonomi Zakat dalam Mengentaskan Kemiskinan: Studi Kebijakan Zakat Umar bin Khattab dan Perzakatan di Indonesia." Laa Maisyir: Jurnal Ekonomi Islam 6, no. 2 (2019): 226-245.

Aqbar, K., \& Iskandar, A. "Kontekstualisasi Kebijakan Zakat Umar bin Abdul Aziz dalam Perzakatan dan Pengentasan Kemiskinan di Indonesia." Kajian Ekonomi dan Keuangan 3, no. 3 (2019): 198-218.

Chaniago, Siti Aminah. Pemberdayaan Zakat Produktif Dalam Pemberantasan Kemiskinan. Jurnal Hukum Islam 10, no. 2 (2012) : 241-260.

Dewan Perwakilan Rakyat dan Presiden. Undang-Undang Republik Indonesia Nomor 23 Tahun 2011 Tentang Pengelolaan Zakat. Jakarta: Departemen Agama Republik Indonesia, t.th.

Djafri, Muhammad Taufan., Askar Patahuddin., Khaerul Aqbar., dan Chaeril Syarifuddin, "Zakat Harta dari Hasil Undian Berhadiah dalam Perspektif Hukum Islam.” BUSTANUL FUQAHA: Jurnal Bidang Hukum Islam 1 No.3, (2020): 390-415.

Domopoli, Muljono. Pedoman Penulisan Karya Tulis Ilmiah Makalah, Skripsi, Tesis, Disertasi, dan Laporan Penelitian. Cet. I; Makassar: Alauddin Press, 2013.

Faisal. "Pendekatan Teori Investigasi Sejarah Charles Peirce dan Defisit Kebenaran Lieven Boeve," Analisis: Jurnal Studi Keislaman 11, no. 2 (2011) : 241-272.

Habibah, Siti. "Zakat Profesi Dalam Pemikiran Fikih Kontemporer Studi Perspektif Ushul Fikih.” Az Zarqa': Jurnal Hukum Bisnis Islam 7, no. 1 (2015) : 133-160.

Herman, Sulkifli, Saifullah bin Anshor, and Akhmad Hanafi Dain Yunta. "Tinjauan Hukum Islam terhadap Pembayaran Zakat Profesi dengan Sistem Payroll (Studi Kasus pada PT. PLN Persero, Unit Induk Wilayah Sulselbar)." BUSTANUL FUQAHA: Jurnal Bidang Hukum Islam 1. No.4 (2020): 650-672. 


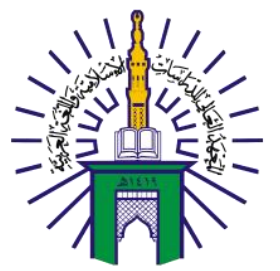

\section{BUSTANUL FUQAHA: \\ JURNAL BIDANG HUKUM ISLAM \\ Vol. 2 No. 1 (2021): Hal. 78-97 \\ EISSN: 2723-6021 \\ Website: https://journal.stiba.ac.id}

Iskandar, Azwar, and Khaerul Aqbar, "ZAKAT DISTRIBUTION POLICY OF UMAR BIN KHATTAB AND COVID-19 CRISIS," Tasharruf: Journal Economics and Business of Islam 5, no. 2 (2020) : 160-178.

Konsideran Undang-Undang Nomor 23 Tahun 2011 Tentang Pengelolaan Zakat.

Mardjono, Hartono. Menegakkan Syariat Islam dalam Konteks Keindonesiaan. Bandung: Mizan, 1997.

Nikmatuniayah, and Marliyati. "Akuntabilitas Laporan Keuangan Lembaga Amil Zakat di Kota Semarang." MIMBAR: Jurnal Sosial dan Pembangunan 31, no. 2 (2015) : 485-494.

RI, Departemen Agama. Al-Qur'an dan Terjemahannya. Jakarta: Almahira, 2017.

Ridlo, Ali. "Zakat Dalam Perspektif Ekonomi Islam.” Al- 'Adl 7, no.1 (2014) : 119-137.

Sangaji, Etta Mamang, and Sopiah. Metodologi Penelitian. Yogyakarta: Andi Offset, 2010.

Saprida. Fiqih Zakat, Shodaqoh dan Wakaf. Cet. I; Palembang: Noerfikri, 2015.

Sarwi, Ahmad. Seri Fikih Kehidupan (4): Zakat. Cet. I; Jakarta Selatan: DU Publishing, 2011.

Sholahudin, Muhamad Afif. "Mengapa Pengelolaan Zakat di Indonesia Masih Belum Efektif?,"

https://www.kompasiana.com/afif114/58c799c1ca23bd3c089ceb66/mengapapengelolaan-zakat-di-indonesia-masih-belum-efektif, (Diakses 31 Maret 2021).

Suharto, Ugi. Keuangan Publik Islam: Reinterpretasi Zakat dan Pajak. Yogyakarta: PSZ STIS, 2004.

Syahrir, Sultan. Pemahaman Masyarakat Terhadap Kewajiban Zakat di Kecamatan Maritengae Kabupaten Sidenreng Rappang. Makassar: Skripsi, Fak. Syariah dan Hukum UIN Alauddin, 2017.

Wibisono, Yusuf. Mengelola Zakat Indonesia. Cet. 2; Jakarta: Kencana, 2016.

Zuhri, Saifuddin. Zakat di Era Reformasi. Semarang: Bima Sejati, 2012.

\section{Sumber Internet:}

Agent of change. https://brainly.co.id (15 Mei 2020).

Arti Kata Pemaksaan Menurut KBBI. https://jagokata.com, (Diakses 24 April 2020).

Paksaan. https://kbbi.web.id/paksa.html, (Diakses 24 April 2020).

Wali Kota Serang Minta Kejadian Warga Meninggal Kelaparan Tak Terulang. www.kabar-Banten.com, (Diakses 26 April 2020). 